\title{
Challenging Corporate Power: Human Rights Globalization from Above and Below
}

\author{
Jackie Smith ${ }^{1}$ \\ Published online: 30 April 2021 \\ (c) Society for International Development 2021
}

\begin{abstract}
To address the most pressing issues of our day, the United Nations must be redesigned to transform global social relations in ways that reduce corporate power and empower civil society and local authorities as global actors. People's movements have made deliberate efforts to advance what I have called human rights globalization, building foundations for an alternative global order from the ground up. These emerging transformative projects can end corporate impunity and foster global norms and identities that contest corporate governance and the monopoly authority of states.
\end{abstract}

Keywords Social movements $\cdot$ Global democracy $\cdot$ Globalization from below $\cdot$ Localization $\cdot$ Polycentric global governance

Today's climate crisis and COVID-19 pandemic have exposed fatal flaws in our systems of governance. Growing numbers of people face preventable premature deaths while the world's richest $1 \%$ continue to accumulate unfathomable amounts of wealth. Our pre-pandemic world of extreme inequality was caught unprepared by a predictable health crisis that has and will deepen the extremes of inequity, deprivation and misery in our world. ${ }^{1}$ The global community now faces a moment of grave danger, alongside opportunities for a fundamental makeover of the UN and related systems of global governance. The alternative to a wholesale re-thinking of how we govern our world is a 'great reset', ${ }^{2}$ led by a concentrated corporate elite committed to the continued accumulation of wealth extracted at unacceptable cost to people and our planet.

Here I argue that to be relevant in the world today, the UN must be empowered relative to global financial institutions so that it can disrupt the powerful idea systems and institutional arrangements that have enabled and sustained today's lethal concentration of wealth and power. The possibilities for such a shift are emergent within the UN system and in civil society movements, which are coming together in new

Jackie Smith

jgsmith@pitt.edu

1 University of Pittsburgh, Pittsburgh, PA, USA ways to prefigure alternative forms of local and global governance. How can more concerted efforts to support these initiatives and unite diverse actors around a global human rights project, led 'from below', address today's pressing challenges?

At this historical juncture, we are faced with a particularly frightening and urgent dilemma: the existing inter-state system has enabled enormous concentrations of wealth and power in the hands of corporate entities that operate beyond the bounds of ethics and law. Too often, politicians and governments are beholden to corporate interests, and thus are unable to govern in ways that serve their constituent communities. And human rights law-never adequately designed or supported by governments-has become increasingly meaningless, as the world's most influential actors-including, notably, powerful states-operate knowing that they cannot be held accountable to these laws, no matter how compelling or urgent to human survival. Tinkering with this exceedingly unbalanced system is futile: it simply cannot be reformed in ways that will enable it to manage today's multiple, deepening crises. An entirely new operating system is needed to reorder social relations in ways that prioritize human survival

\footnotetext{
${ }^{1}$ Oxfam's 2021 report, The Inequality Virus. This study found that more than two thirds of economists from around the world who responded to Oxfam's survey $(67 \%)$ believed their government had no plan in place to mitigate the inequalities fueled by the COVID-19 pandemic. https://www.oxfam.org/en/research/inequality-virus.

${ }^{2}$ https://www.weforum.org/great-reset.
} 
and put the needs of people and communities over wealth accumulation. In short, we need a commitment to implement Article 28 of the Universal Declaration of Human Rights (UDHR), which declares: 'Everyone is entitled to a social and international order in which the rights and freedoms set forth in this Declaration can be fully realized.'

What would such an order look like? Is such a radical change possible? How? Fortunately, people's movements have been working to answer these questions and build foundations for an alternative global order from the ground up. They draw inspiration, strength, and unity from the existing human rights architecture that has grown in large part from the heroic struggles of these very movements. I draw from my own research and praxis as part of these social movements, distilling what I think are emergent ideas for transforming our global governance architecture by working simultaneously from 'above' and from 'below'.

The project of human rights globalization advanced over centuries by constellations of civil society and other actors provides a framework and a foundation for a re-imagined global architecture (Smith 2008, 2021; Sklair 2009). After outlining what I think is the most important challenge- the global concentration of corporate power-tracing its institutional bases and supports, this essay looks briefly at the human rights movement and the trend of growing engagement of local and trans-local communities working to 'bring human rights home' to the places where they matter most. As these activists work locally and globally to articulate a vision for human rights globalization, they are forging a foundation to make a radically transformative, life-centred project possible. Some promising movement initiatives that can advance a 'social and international order in which the rights and freedoms set forth in [the UDHR] can be fully realized' are highlighted.

\section{The Current Dilemma and its Causes}

Today's biggest challenges-most notably inequality, environmental collapse, and growing violence - can all be linked at least in part to the problem of corporate power. The UN system has the potential to challenge the hegemony of corporations and the elites who use and manage them. But for the last several decades it has been used to support an elite project of capitalist expansion and neoliberal globalization, enabling the growth of new corporate 'shadow sovereigns'

\footnotetext{
3 The ideas conveyed here are therefore ones I cannot claim as my own. Rather, they reflect emergent movement wisdom, and their authors are innumerous activists from movements past and present. I acknowledge the contributions to my thinking from so many fellowactivists I have been honoured to work with and learn from over many years.
}

(George 2015). To fulfill its ideals, the UN must embrace a people- and life-centred project of 'human rights globalization', which requires a fundamental paradigm shift and a radical democratization of government based on the sovereignty of 'we the peoples of the United Nations'.

The global debt and energy crises that converged in the 1970s shifted the global development agenda in favour of a neoliberal economic approach that, over time, has favoured the private sector over governments, global trade and foreign investment over domestic economic development programmes, and technical expertise over democratic processes. International trade agreements, aid and loans were all designed to open domestic markets to global competition, reduce government regulation of finance and worker and environmental protections, and encourage foreign investment. In its 2018 report, the UN Conference on Trade and Development (UNCTAD) provided a stark assessment of these policies:

Over the last four decades, a mixture of financial chicanery, unrestrained corporate power and economic austerity has shredded the social contract that emerged after the Second World War and replaced it with a different set of rules, norms and policies, at the national, regional and international levels. This has enabled capital - whether tangible or intangible, long-term or short-term, industrial or financial - to escape from regulatory oversight, expand into new areas of profitmaking and restrict the influence of policymakers over how business is done.

Thus, although proponents promised that this policy programme would generate economic growth and development, instead it has brought declining fortunes and more inequality for most countries and workers. Many analysts have shown how this economic and political project has systematically transferred wealth from poorer countries, people, and ecosystems to richer ones, reflecting what David Harvey and others have called 'accumulation by dispossession'.

Analysts have argued that a 'transnational capitalist class' (Sklair 2001) uses lobbying, control of the mass media, think tanks and politicians to promote its neoliberal, consumerist ideology and its worldwide application in global trade and financial agreements. Since the 1970s, a loose configuration of actors with parallel interests were able to both promote and benefit from the following:

- The global hegemony of market ideology and a culture of consumerism;

- Prioritization of economic growth over other social goals in public policies at all levels;

\footnotetext{
${ }^{4}$ In a more recent assessment, Robinson (2020) calls this a process of 'accumulation by repression'.
} 
- Institutional contradictions enabling trade and finance laws to override UN and government human rights obligations;

- Laisses-faire oriented global rules that reduce governments' capacities and enable corporations to shift risks and costs onto workers, communities and the environment;

- The co-optation or capture of governments and public institutions (including the UN) and appropriation of public resources by private actors;

- The privileging of global over local scales (Peet 2003; Bello 2000; Smith 2008; Dine 2009; Robinson 2014; Santos 2006a).

This 'globalization from above' must be dismantled and replaced with a democratic and responsive system of global and local governance in order to protect humanity from continued, deadly processes of corporate extraction. Transnational Corporations (TNCs) now control around $80 \%$ of all global trade, and over recent decades, they have become predominate in the world's top economies (Carroll 2010; George 2015). By 2016 of the top 100 world economic entities, 69 were corporations and just 31 were governments. Of the top 200 economies, 157 are corporations (Global Justice Now! 2016). Thus, it should not surprise us that government responses to recent global crises have only reinforced growing inequities (Collins 2020; Oxfam International 2020).

In short, the UN and many of its member states have enabled an unsustainable, hierarchical system of extraction and empowered corporations as dominant global actors, while diminishing the power and legitimacy of elected governments and the communities they serve. Analysts are increasingly highlighting the predatory nature of this system, describing it as 'rentier capitalism', or more vividly, 'vulture capitalism', where the real rulers are non-human entities legally designed to extract profits by shifting risks and costs to communities (Dine 2006; Standing 2016; Bakan 2020). This leadership vacuum enables authoritarian populism to thrive. To counteract this we need to transform cultural as well as the institutional and material foundations that empower corporations and marginalize 'we the peoples'.

The groundwork for these changes, I argue, has been developed over many decades by human rights advocates around the world. A long tradition of struggle by oppressed peoples who have come together to fight slavery, advance women's political and social power, and defend cultures and livelihoods have collectively enacted a long-term project of human rights globalization. This counterhegemonic project involves cultural and institutional work and provides a blueprint for realizing the UDHR's Article 28.

\section{Human Rights Globalization: An Emergent Alternative System}

Against the project of globalization from above, varied constellations of popular groups have been advancing-albeit largely unselfconsciously - an alternative vision for how the world could be organized to serve people's needs. Movements to end slavery, advance rights for women, and protect workers and the environment have collectively shaped a global system of norms, values and institutions that support human rights (Sikkink 2011, 2017). These efforts have strengthened the legal and institutional bases for human rights protections, supported the democratization of global institutions and the development of new human rights actors, and advanced the localization of global governance. These all help improve human rights conditions and strengthen the legitimacy and effectiveness of multilateralism in the UN system (Kaldor 2003).

Often operating around specific campaigns and constituencies, diverse movements have supported a system of international law and institutional machinery that improves implementation of laws protecting human rights and ecosystems. For instance, many years of transnational advocacy led to the creation, by member states, of the Office of the High Commissioner for Human Rights (OHCHR) in 1993.

This office, in turn, has strengthened what is now the Human Rights Council as it coordinates the mainstreaming of human rights values throughout the UN system. It has also enabled more systematic, routinized, and synchronized efforts to monitor the human rights commitments made by member states through the variety of international legal instruments and monitoring bodies. In particular, the designation of 'special procedures' to facilitate fact-finding, transparency, and in-depth analyses of particular areas of human rights such as housing, health, racial equity, and poverty, combined with the establishment of the Universal Periodic Review in 2006 have substantially strengthened human rights monitoring and accountability processes. Such institutional arrangements expand the meager budget allocated to the UN's human rights work by mobilizing and coordinating largely volunteer labour from both high-level experts and from activists and organizations in civil society. As a result of these efforts, the global human rights architecture in place today—while still lacking in many respects—provides a much stronger foundation for contemporary advocates to contest the neoliberal globalization project.

This process has nurtured networks of activists, professionals, and public officials working across local and global scales who are well-versed in international human rights laws and their articulation in a variety of global treaties and institutions. By providing opportunities for local and national activists to challenge abuses, global human rights 
machinery has encouraged local reframings of conflicts in human rights terms and the translation of formal human rights laws and standards into local settings (Smith and Cooper 2019). As activists have engaged with UN processes, they have embraced new understandings of human rights and of their own identities and possibilities for agency beyond their local and national contexts (Tsutsui 2018). A slogan of human rights city activists- 'human rights don't trickle down, they rise up'-helps illustrate their sense of local agency and of their role in global human rights governance. ${ }^{5}$

\section{Localization of Global Human Rights Movements}

One other key development is the localization of the global human rights movement since the 1990s. Whereas earlier periods of human rights advocacy centred around the development of international treaties and arrangements for global monitoring of human rights, it was clear by the early 1990s that this top-down approach was seriously limited in its ability to improve conditions for most people. In short, governments proved willing to ratify human rights treaties, knowing that there was little likelihood they would face serious pressure to change their policies and practices. But the end of the Cold War opened new possibilities for addressing economic and social rights and highlighting their unavoidable intersections with political and civil rights. This period also saw expanded growth of all kinds of transnational social movement activism, supported in part by new communications technologies as well as by the sequence of UN-sponsored world conferences.

Civil society organizations and related transnational movement networks exchanged ideas and analyses as their organizing shaped their understandings of the UN and its limitations. Activists strategized over how to address what they recognized as growing corporate influence in the UN and other international bodies. They continued to puzzle over how best to counter a growing elite backlash against civil society and improve the translation of global treaty commitments into local policy practices. The lessons they generated shaped the Final Declaration of the 1993 World

\footnotetext{
5 The slogan echoes Frederick Douglass's observation that power concedes nothing without a demand.
}

Conference on Human Rights in Vienna, which in addition to establishing the OHCHR encouraged greater efforts to integrate global human rights efforts within local governments and civil societies (van den Berg and Oomen 2014). The Vienna Conference also named the 1995-2004 decade the 'Decade for Human Rights Education', promoting more work to popularize and localize human rights ideals and values. A network of human rights advocates created out of that meeting, the Peoples Decade for Human Rights Education (PDHRE), ${ }^{6}$ supported a 'human rights city' initiative aimed explicitly at translating global human rights norms into local community settings. ${ }^{7}$

Thus, the early 1990s brought new institutional arrangements at the global level and strengthened capacities for global organizing by increasingly coherent networks of political activists who were able to operate across global and local scales. The rise in the latter part of the 1990s of global justice movements demanding fundamental changes in the global trade and financial system encouraged even more global networking and the development of analyses about the intersections of economic and other rights, and they helped highlight the fundamental contradictions between human rights and the global economy.

The World Social Forum's ongoing, multi-scalar process provided important global, national, regional and local spaces where movement activists have strengthened their movements and networks while deepening understandings of neoliberal, 'corporate' globalization's impacts across diverse settings (Smith and Wiest 2012). ${ }^{8}$ The following table draws from movement documentation, observations and secondary analyses to synthesize the modes of thinking that are evident in these diverse movement efforts, contrasting these with the prevailing neoliberal globalization paradigm.

\footnotetext{
${ }^{6}$ https://pdhre.org/about.html. This group has changed its name to Peoples Movement for Human Rights Learning.

7 This is one of the main streams of organizing in different sectors and parts of the world that has shaped a global movement for the 'right to the city' and supported more engagement from local governments in trans-local efforts to address critical social problems. This tendency is increasingly understood as a contemporary global rise of 'municipalism' (Baird 2017; Smith 2020).

8 On the World Social Forums (Santos 2006b; Sen and Waterman 2007; Smith et al. 2011; Smith 2020).
} 


\section{Competing Frameworks for Global Governance $^{9}$}

\begin{tabular}{|c|c|c|}
\hline & $\begin{array}{l}\text { Hegemonic inter- } \\
\text { state, capitalist } \\
\text { globalization }\end{array}$ & $\begin{array}{l}\text { Counter-hegemonic } \\
\text { human rights globali- } \\
\text { zation }\end{array}$ \\
\hline Orienting goal & $\begin{array}{l}\text { Wealth accumula- } \\
\text { tion, economic } \\
\text { growth }\end{array}$ & $\begin{array}{l}\text { Human rights and } \\
\text { well-being/buen } \\
\text { vivir }^{\mathrm{a}}\end{array}$ \\
\hline $\begin{array}{l}\text { Relationship with } \\
\text { ecosystems }\end{array}$ & $\begin{array}{l}\text { Anthropocentric, } \\
\text { extractive }\end{array}$ & $\begin{array}{l}\text { Life-centered, steward- } \\
\text { ship/sustainable use/ } \\
\text { Pachamama }^{\text {b }}\end{array}$ \\
\hline Social relations & $\begin{array}{l}\text { Focus on Individual } \\
\text { Hierarchical, based } \\
\text { on gender, nation, } \\
\text { race, and class }\end{array}$ & $\begin{array}{l}\text { Focus on community } \\
\text { as foundation for } \\
\text { individual rights and } \\
\text { well-being/Ubuntu } \\
\text { Horizontal/egalitarian }\end{array}$ \\
\hline Relational logics & Competition & Cooperation \\
\hline $\begin{array}{l}\text { Primary scale of } \\
\text { decision making \& } \\
\text { economy }\end{array}$ & Global & Local \\
\hline $\begin{array}{l}\text { Policymaking } \\
\text { authority }\end{array}$ & Elite, technocratic & Democratic \\
\hline Locus of sovereignty & $\begin{array}{l}\text { National govern- } \\
\text { ments }\end{array}$ & $\begin{array}{l}\text { People and communi- } \\
\text { ties (subsidiarity) }\end{array}$ \\
\hline $\begin{array}{l}\text { Key proponents and } \\
\text { institutions }\end{array}$ & $\begin{array}{l}\text { States, transnational } \\
\text { corporations, inter- } \\
\text { national financial } \\
\text { institutions }\end{array}$ & $\begin{array}{l}\text { Civil society/com- } \\
\text { munities, some states } \\
\text { and some UN and } \\
\text { multilateral agencies }\end{array}$ \\
\hline
\end{tabular}

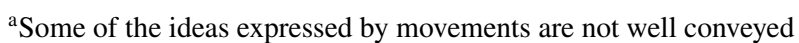
using English language terms, so the terms shared by movement participants are included here

${ }^{\mathrm{b}}$ This term refers both to the understanding of the Earth as motherthe source of life, but it is more complex in that it conveys a sense of interdependence and responsibility, a 'land ethic' in the sense articulated by Aldo Leopold

${ }^{\mathrm{c}}$ Corporate influence in and corruption of governments the UN and related agencies is a pervasive challenge for multilateralism in general and for human rights and democracy movements in particular (Smith et al. 2017)

This table can be a useful guide to those seeking to imagine and design a global architecture that can support practices and modes of community life that are more democratic, equitable and sustainable than the existing UN framework. What is noteworthy is that the vision conveyed here is so widely reflected in discourses and platforms put forward by a great diversity of people and movements around the world (Chase-Dunn et al. 2007; Steger et al. 2013; Carroll 2016).

\footnotetext{
9 Some key articulations of these ideas made by people who have been active in these movements include: Bello (2003), Broad and Hecksher (2003), Cavanagh and Mander (2004), Carroll (2016), Norberg-Hodge (2019).
}

This suggests that efforts to design and build new global architecture are both within our sights and likely to help unify diverse social formations. The challenge is altering the vast disparities in power that perpetuate the existing, corporate-led order.

It is worth recognizing that civil society and social movements have long been essential to transformative multilateral initiatives, beginning with the earliest efforts to counter the barbarism of slavery and war. Yet, the resulting institutional architecture marginalizes these actors as agents of global governance. Most state-centred accounts downgrade the significance of social movement and civil society actors in multilateral initiatives, if they recognize them at all. Yet, understanding this long history of struggle and its results can guide our thinking today. I see the work ahead in terms of two fronts of struggle, simultaneously working to transform both the ideas and the structures that enable corporate hegemony. Specifically, we must roll back the power of corporations and the transnational capitalist class while also building and popularizing grassroots alternatives to economic globalization, thereby implementing a life-centred human rights globalization (Bello 2003).

\section{Changing Ideas, Discourse and Culture}

The globalization project has effectively enabled corporations to become 'moral deflection devices', which, according to corporate legal scholar Janet Dine, '[conceal] the underlying mechanisms at work within the international financial order, [providing] huge incentives to those who would favour corruption and despotism, and huge disadvantages and disincentives for struggling democratic regimes' (Dine 2009: 62 ). The result is economic totalitarianism, where corporations are able to use the façade of democracy to legitimate policies and practices that are literally killing communities and destroying our health (Chapman 2017). Human rights are used to express moral outrage with these trends, but corporate corruption of national and global institutions denies them any ability to compel meaningful changes in practices.

Reducing the destructive power of corporations in our world will require a delegitimization of the idea-system from which their power grows, alongside concerted efforts to reduce their ideological power. Global governance for our future depends upon widespread rejection of market fundamentalism and its illogic of endless, uneconomic growth (Daly 2012) in discourse and policy at all levels. In its place, we need a vision that centres life and care. Other ideological foundations that must be rejected are the privileging of states in global governance, the separation of nature and society and related gender and racial hierarchies, and the hierarchy of global over local scales. All of these ideas 
effectively reinforce the power of corporations over communities and threaten our survival.

As we work to challenge the hegemony of market fundamentalism, we must also contest the idea that larger scales are somehow better, more efficient, and essential to 'progress'. To 'deglobalize' our thinking is to also 'decolonize' and re-localize it. Seeing the globalization project as a form of extractive colonialism illuminates how today's global elite benefited from centuries of organized exploitation that they reproduce in contemporary ideas and institutions. Production, trade, and political decision making is more responsive and amenable to meaningful forms of democratic participation if it is locally defined and controlled. The costs and effects of policies are more visible to the people they concern, and thus they are more sensitive to social needs and ecological conditions. Of course, local control is not always desirable when policies have impacts beyond particular communities, so an alternative global architecture must privilege the principle of subsidiarity, which emphasizes decentralized decision making that remains as close to the local level as possible. This flips the current script of politics, which requires communities to adapt to globalized rules made without local participation or consideration of local needs. ${ }^{10}$

The rise of right-wing fundamentalism over recent decades reflects a failure of prevailing institutions to provide for people's basic needs and to cultivate an inclusive culture of human rights and democracy. Prioritizing individual competition and property rights has led to widespread precarity and social exclusion, impoverished the commons and undermined social cohesion. Decades of neoliberal policies have extracted not only labour and resources from our communities, but they have seriously threatened the social systems that support them. Conscious attention to cultivating a life ethic, re-valuing the local and our ecosystems and fostering participatory democratic values can both rebuild communities and deny corporate globalization the ideological support it needs. It can also help actively engage people and communities in a project that inspires them, at a time when more and more people are losing faith in the existing, increasingly unstable, global order.

These changes in thinking will re-orient individuals' identities in ways that enable a shift in the UN system away from its state-centred and competitive model towards one that prioritizes cooperation and human interests over the interests of the most powerful states. Yet, abandoning such an entrenched and well-defended system of thought will require the promotion of alternative economic and social orders that

\footnotetext{
${ }^{10}$ Many of the ideas outlined in this and the following section draw from Alternatives to Economic Globalization: A Better World Is Possible, an important synthesis of analyses and proposals that builds on the work of dozens of activists and movement traditions worldwide (Cavanagh and Mander 2004).
}

provide for people's needs and model the values of a peoplecentred society. Uncertainty and fear of the unknown will lead many if not most people to defend a familiar, if illogical and doomed system, so demonstrating the viability and desirability of a system that prioritizes care and dramatically scales back consumption is a critical task. Projects such as de-growth and foundational or care-driven economies ${ }^{11}$ are important in this regard, and they are gaining traction by reviving people's political imaginations and demonstrating the feasibility of alternatives. This disrupts corporate ideological hegemony, opening even more space for imagination and innovation. These projects will, however, remain limited as long as corporations retain their structural power-that is, their control over material and economic resources and their related political influence. This will require some fundamental shifts in how power is organized globally.

\section{Structural Transformation}

The ideological hegemony of corporate globalization obscures the fact that the extractive model of the global economy assumes an endless supply of the raw materials for what it calls 'production'. This model regards cities and other communities not as care- and life-producing dwelling places, but as sites for wealth accumulation. It promotes the image of corporations as providers of jobs and irreplaceable agents of progress and social good (Bakan 2020). In so doing it allows corporations to effectively colonize cities and engage in the very same extractive processes seen under slavery and in mining industries and sweatshops. What is extracted is the lifeblood of communities: the land that houses and nourishes human and other populations, the small business opportunities that support inclusive economies and reinforce community relationships as well as wealth, and the clean water and air that is essential to livelihoods and ecosystems.

When so many people must put all their time and energy into meeting basic needs within this economic order, they cannot be full participants in democratic politics and community life. This has enabled elites to deplete communities in the same way that industrial agriculture depletes the soil. Processes of industrialization and urban gentrification/displacement destroy connections between people and places. Such social connections resemble the underground root systems that nourish and stabilize life above ground. ${ }^{12}$ To hold policymakers and corporate actors accountable, community

\footnotetext{
11 https://www.degrowth.info/en/feminisms-and-degrowth-alliancefada/collective-research-notebook/; https://foundationaleconomy.com.

12 Mindy Fullilove's Root Shock (2016) for an elaboration of this metaphor and documentation on the health impacts of urban displacement.
} 
members must have skills and time to build allegiance to place and communities. This requires attending public meetings, doing research and otherwise monitoring government practices, working to ensure transparency, hold officials accountable and developing solutions. The global competitive economy and scaled back welfare state denies citizens the ability to perform these basic democratic functions, and corporate actors have been happy to fill the leadership vacuum. Thus, we need to promote local democratization and embed the economy within the social order (Munck 2002). Like the work of nurturing future generations, democratic governance is care work that must be valued and recognized as socially productive labour. It must be provided with the necessary time and resources to enable participation by all people and communities.

The new global architecture must therefore disable corporate extraction and dismantle the corporate 'shadow sovereigns' that corrupt local and global democracy and threaten global peace and security (George 2015). Concrete programmatic steps are needed to legitimate and enable popular sovereignty, which will in turn help bring much needed legitimacy to our failing global institutional order. Ultimately, we need a global system designed to value care and provide material support for all aspects of social reproduction. Specifically, we need policies and institutions that enable, encourage and reward the work of democratic governance and community-building. Moreover, protections of collective rights to land and clean environments are essential to providing the foundation upon which all of this depends. ${ }^{13}$

\section{Towards People-Centered Global Governance}

Although claiming to represent 'the peoples', we must recognize the United Nations system as a negotiated compromise among powerful states that effectively excludes the majority of states and people from decisions that directly affect their well-being. These arrangements are justified and legitimated by claims that they reflect ideals of human rights, democracy and equality. Such institutionalized contradictions have undermined global peace and security since their introduction, and they lie at the heart of today's multiple and interlinked crises that threaten to destroy all that is familiar. Even elite groups such as the World Economic Forum and Atlantic Council recognize emerging 'signs of a systemic

\footnotetext{
13 This requires basic changes in laws related to private property (Dine 2006; Standing 2016; Meyersfeld 2017).
}

malfunction in the global governance framework' (Lissovolik 2019). Predictably working to protect their privilege and power, such groups are now calling for renewed efforts to restore the rule of law by introducing limited equity and accountability in the system (Jain and Kroenig 2019; Friedman 2017). Yet, the solutions being proposed from these commanding heights will only reinforce the inequities and exclusions that have caused untold suffering for the majority world (Johnstone 2020; Klein 2020).

The marginalization of most countries of the Global South in UN decision-making and the absence of a mechanism for holding states accountable to their citizens creates a democratic deficit that has long hampered the institution's legitimacy and effectiveness. The fact that it has enabled the development of an increasingly exclusionary and inherently violent system based on the 'savage sorting of winners and losers' (Sassen 2014) contributes to the legitimacy crisis in global governance today. ${ }^{14}$ Lacking a voice and a stake in the existing global order, marginalized people and communities see little to lose by following the lead of authoritarian populists, and an increasingly concentrated and entrenched global oligarchy readily converts the resulting social divisions into lucrative sources of profits. The survival of the UN and its greatest principles will require concerted work towards a multilateral order that can offer a compelling and hopeful alternative that can build local and global unity and win the trust and support of more of the world's people.

The rise of global authoritarian movements and corruption of democratic institutions in countries around the world is a response to global oligarchy and the inequities it produces, which now pose immediate threats to the existing global order. But the world's economic and political elites continue to ignore this system's injustices, denying the world's majority a meaningful stake in a shared global order and fueling the flames of right-wing populism. The future of peace and human security therefore requires a radical transformation of global institutions to make them more inclusive and responsive to people's basic needs and to remedy the serious gaps in the accountability of powerful actors to global norms - as even elite analysts acknowledge (Lissovolik 2019).

Curbing anti-democratic authoritarian tendencies requires giving more of the world's people and communities a real stake in a system that ensures their livelihoods and protects future generations. This requires a concerted, substantial

\footnotetext{
14 This legitimacy crisis is not limited to the UN, and indeed the UN's legitimacy relies on that of its member states, which have long been in decline, in part due to the expansion of the global neoliberal order (Markoff 1999; Foa et al. 2020).
} 
and principled redistribution of material wealth and political power aimed at radically democratizing the global economic and political system. To do that, we need a re-envisioned/ reimagined global leadership to both reduce the power of transnational corporations while empowering and uniting grassroots democratic forces in a more inclusive project of 'globalization from below'. ${ }^{\prime}$

\section{Realizing a New Vision}

The above analysis of the ideological and structural sources of corporate power leads to the conclusion that the future of the UN is in the creation of a global architecture that flips our political script from an emphasis on profits to people and shifts power from private to public entities. A multilateral framework that privileges popular over state sovereignty and empowers local authority in global governance and a renewal of the principle of subsidiarity is essential. The UN's first 75 years have centred the voices of states and failed to realize effective multilateral governance. Subsidiarity requires greater efforts at regional and other scales to improve understanding, coordination and communication across locales and to empower cities and other local governments as sites of trans-local decision-making. Unlike at the UN's founding, there is now far greater capacity for this mobilization of polycentric authority, and this is the only remedy for the disastrous governance failures of the existing system. Yet, some key ideological and structural actions are needed to advance this vision. These include:

- Promote systematically a project of human rights globalization that subordinates transnational corporations and powerful governments to human rights laws and standards by strengthening the OHCHR and related human rights machinery.

- Empower people and local governments as global political actors in a democratized multilateral system.

- Explicitly oppose the hegemony of market fundamentalism reflected in neoliberal ideology and promoted in mainstream corporate media and policy discourse.

- Confront and reverse processes of digital colonization by corporate tech monopolies; enable and support a democratically controlled system of global information and communication.

- Reverse neoliberal policies to empower democratically controlled governments from local to global levels as guardians of the well-being of people and communities.

\footnotetext{
15 As an analysis included on the World Economic Forum's platform points out ' $[\mathrm{t}] \mathrm{he} \mathrm{UN}$ desperately requires mechanisms that enable individuals to seek redress and to hold accountable those who caused harm' (Friedman 2017).
}

Of course, these represent radical changes in the status quo, and many will call this vision utopian and politically unrealistic. However, the existing order is already unlivable (unrealistic) for many, and it also happens to be collapsing. This will open space for some alternative that will necessarily look unrealistic in terms of the existing power relations. As constructed, the UN system has failed to serve its core purpose of promoting international cooperation for peace and security. It needs a fundamental makeover in order to survive. The alternative is continued ecological collapse and the growth of exclusionary and anti-globalization political forces that threaten our already weakened foundations for local—much less global—solidarity. Despite its weaknesses, the world needs a UN as a focal point for unity and a framework for managing global interdependence.

While the view from above might look bleak, the work that has long been happening 'from below', in the movements of people demanding a better world, provides a basis for a transformation of global social relationships and more effective and democratic global governance. Concerted and deliberate efforts by social movements and by government actors at local, national and global levels to advance and develop these projects can help build the world we need. Three particular areas illustrate where work is already happening in this regard.

\section{Rolling Back Corporate Ideological Power}

First, the New World Information and Communication Order (NWICO) is a transformative project that has been advanced since the UN's early days by social movements and governments in the Global South. Conversations about how to democratize the global media system and prevent the corporate-controlled system that now propagates corporate-serving propaganda and fuels global consumerist culture have continued, even as dominant forces have obscured their presence and blunted their impacts. This process has articulated norms and values to guide media policy, reflected in the 1980 MacBride Report, which advanced five areas for government action deemed essential for effective democratic governance:

1. Include communication as a fundamental right;

2. Reduce imbalances in the news structures;

3. Strengthen a global strategy for communication while respecting cultural identities and individual rights;

4. Promote the creation of national communication policies to be coherent and lasting in the processes of development;

5. Explore how the NWICO could be used to benefit a New International Economic Order (NIEO). ${ }^{16}$

\footnotetext{
16 https://en.wikipedia.org/wiki/New_World_Information_and_ Communication_Order.
} 
The NWICO principles have been further supported and advanced in the 1991 Windhoek Declaration for the Development of a Free, Independent and Pluralistic Press advanced by African newspaper journalists. This Declaration helped shape the development of metrics to assess media democracy and effectiveness and advanced the formation of UNESCO's International Programme for the Development of Communication Intergovernmental Council in 2006. ${ }^{17}$

These foundations can be a focal point for uniting global people's movements and democratic world leaders around concrete principles and structural reforms that can improve global media ecosystems. Indeed, the recognition of the current system's dysfunction and its role in exacerbating the impacts of the COVID-19 by fueling a global 'infodemic', should open the way for transformative change. Moreover, such changes from above will both help advance and build an already rich and expansive movement for equitable global internet governance, digital democracy, and democratic communication. Widespread are social movements of independent journalists and democratic media outlets, open access and open source software activists, and movements for data sovereignty and digital rights. Releasing these popular forces from regulatory structures corrupted by corporate political influence, and enabling them the resources needed to thrive and grow will help grow a more democratic information system that can effectively govern today's communication ecosystem and build social cohesion rather than fuel hatred, violence, and polarization.

\section{Establishing the Primacy of Human Rights over Corporate Globalization}

Second, there are important projects and knowledge emerging from the human rights globalization work described above. Some key elements of this work should be prioritized in order to rein in corporate power and create possibilities for strengthening democracy and global governance. World leaders must be committed to strengthening global human rights institutions and their capacities relative to corporations and business entities. In particular, we need to highlight and remedy the incompatibilities between human rights and the international legal agreements and the institutions governing trade and finance. These latter entities all must be subordinated to the United Nations system and its human rights architecture centred in the Office of the High Commissioner for Human Rights and its special procedures.

Substantive steps are needed to subordinate TNCs to international human rights laws and to empower people to defend these rights and their basic needs, and the Global Campaign to Reclaim Peoples Sovereignty, Dismantle

$\overline{17}$ https://en.unesco.org/programme/ipdc/.
Corporate Power and Stop Impunity has outlined important steps in this regard. ${ }^{18}$ Led by more than 250 civil society groups from around the world, this campaign calls not only for a binding international treaty to end corporate immunity, but it also demands a 'People's Treaty on the Control of Transnational Corporations'. The people's treaty is needed, advocates argue, because 'We, the people, are the protagonists, political actors and originators of the laws and norms of a political, economic and legal system that will end the current framework of extraordinary privileges and impunity enjoyed by transnational corporations'. Drawing from successful transnational struggles such as that documented in Broad and Cavanagh's The Water Defenders (2021), civil society leaders are recognizing their power as global actors: 'we, besides states can make law: we defend the notion of an international law 'from below'. Therefore, we use the word 'Treaty' in a way that is radically different from the current legal norm. ${ }^{19}$

\section{Supporting Decolonized Transnational Identities and Collectives}

Third, as the Global Campaign to Reclaim Peoples Sovereignty acknowledges, we need to transform global governance and recognize the important roles that diverse actors play. States can no longer retain a monopoly of authority in global governance. Not only have they proved incapable of addressing major threats to our survival, but they reproduce colonial exploitation and encourage a competitive politics of division and exclusion, essentially undermining the UN's core mission. To advance global peace and security, the global community must explicitly authorize and empower non-state and trans-state actors and thus democratize a decolonized global governance.

Promoting new transnational identities and polycentric forms of governance that empower local and regional authorities and non-state actors will both aid the work of finding solutions to urgent global problems, and it will engage more of the world's people to embrace the difficult work required. Again, social movements working 'from below' have advanced numerous models for how such

\footnotetext{
$18 \mathrm{https}: / / \mathrm{ww} w$. stopcorporateimpunity.org/.

19 https://www.stopcorporateimpunity.org/request-solidarity-actions/. This sentiment is reflected in a number of other civil society initiatives to localize human rights treaties and principles, such as the Cities for CEDAW initiative (http://citiesforcedaw.org/), the C40 Cities Network (https://www.c40.org/), and the Fossil Fuel Non-Proliferation Treaty (https://fossilfueltreaty.org/). UN agencies are also recognizing their need to support and strengthen local engagement in order to fulfill their missions (UNICEF's Child Friendly Cities initiative https://childfriendlycities.org/ and OHCHR's Local Government and Human Rights https://www.ohchr.org/EN/Issues/LocalGovernment/ Pages/Index.aspx).
} 
trans-state governance can happen. For instance, the development in 2008 of the Permanent Forum on Indigenous Issues grew from indigenous human rights movements, and a related effort to expand on this model is the emerging Permanent Forum on People of African Descent. ${ }^{20}$ In addition, the 2019 UN Declaration on the Rights of Peasants helps establish people's rights vis-à-vis corporations and articulates a global identity of food producers and the rights of people to healthy ecosystems that enable their 'food sovereignty' and survival. And UN Women, established in 2011, advances the transnational/ trans-state interests and identities of women, helping challenge patriarchal structures and amplifying the importance of care and care work on the global agenda. The final declaration of the 2010 Cochabamba World People's Conference on Climate Change and the Rights of Mother Earth is yet one more example illustrating how popular movements can and must become the prime movers to advance global solutions to our environmental crisis. ${ }^{21}$ In essence, these developments lay a foundation for global popular sovereignty, countering states' monopoly in the UN and encouraging the development of trans-local and trans-state identities and political constituencies. Such 'globalization from below' centres human rather than nationally defined interests and needs in global governance, and paves the way for the more inclusive forms of representation and voice needed to address today's urgent problems.

In conclusion, the UN is at a critical juncture in its history. It can no longer continue operating as in the past, and fundamental changes are needed to centre people over economic values and to support new identities and practices of polycentric global governance. The groundwork for such radical transformation has been laid by bold and creative people working in social movements, in government offices at different levels, and in the UN and other international agencies. By nurturing these tendencies and encouraging greater democracy at all levels of government-from local to global - and by abolishing the concentration of corporate power and impunity, we can realize a sustainable world that ensures well-being for all.

Acknowledgements I am grateful for the invitation to contribute to this special issue and to consider the critically important question posed here. I appreciate the helpful feedback from Barbara Adams on an earlier draft of this article.

\footnotetext{
20 The UN General Assembly passed a resolution (A/C.5/75/18) calling for improved follow-up to the Durban Declaration and Programme of Action and a high-level meeting of the General Assembly in fall 2021 to commemorate the 20th anniversary of its adoption.

${ }^{21}$ See the People's Agreement of the World People's Conference on Climate Change and the Rights of Mother Earth (https://pwccc. wordpress.com). This conference of heads of state and civil society groups was convened by the government of Bolivia in response to the repeated failures of states to take action on climate change.
}

\section{Declarations}

Conflict of interest This contribution is free from any conflicts of interest, including all financial and non-financial interests and relationships.

\section{References}

Baird, Kate Shae. 2017. A New International Municipalist Movement Is on the Rise - From Small Victories to Global Alternatives. Open Democracy.

Bakan, Joel. 2020. The New Corporation: How "Good" Corporations are Bad for Democracy. New York: Vintage Books.

Bello, Walden. 2000. Building an Iron Cage: Bretton Woods Institutions, the WTO, and the South. In Views from the South: The Effects of Globalization and the WTO on Third World Countries, ed. Sarah Anderson, 54-90. Chicago: Food First Books.

Bello, Walden. 2003. Deglobalization: New Ideas for Running the World Economy. Zed Books.

Global Justice Now! 2016. 10 biggest corporations make more money than most countries in the world combined

Broad, Robin, and John Cavanagh. 2021. The Water Defenders: How Ordinary People Saved a Country from Corporate Greed. Beacon Press.

Broad, Robin, and Zahara Hecksher. 2003. Before Seattle: the Historical Roots of the Current Movement against Corporate-led Globalisation. Third World Quarterly 24(4): 713-728.

Carroll, William. 2010. The Making of a Transnational Capitalist Class: Corporate Power in the 21st Century. New York: Zed.

Carroll, William. 2016. Expose, Oppose, Propose: Alternative Policy Groups and the Struggle for Global Justice. New York: Zed.

Cavanagh, John, and Jerry Mander, eds. 2004. Alternatives to Economic Globalization: A Better World is Possible, 2nd ed. San Francisco: Berrett-Koehler Publishers.

Chapman, Audrey R. 2017. Global Health, Human Rights, and the Challenges of Neoliberal Policies. New York: Cambridge University Press.

Chase-Dunn, Christopher, Christine Petit, Richard Niemeyer, Robert A. Hanneman, and Ellen Reese. 2007. The Contours of Solidarity and Division among Global Movements. International Journal of Peace Studies 12(2): 1-16.

Collins, Chuck. 2020. Updates: Billionaire Wealth, U.S. Job Losses and Pandemic Profiteers. In Blogging Our Great Divide, edited by inequality.org.

Daly, Herman. 2012. Uneconomic Growth Deepens Depression, The Daly News: Steady State Commentary and Related News. https://steadystate.org/uneconomic-growth-deepens-depression/. Accessed 20 Feb 2021.

Dine, Janet. 2006. Using Companies to Oppress the Poor. In Human Rights and Capitalism, ed. Janet Dine and Andrew Fagan, 48-79. Northampton, MA: Edward Elgar Publishing.

Dine, Janet. 2009. Rigging the Risks: Why Commercial Law Kills. Irish Pages: A Journal of Contemporary Writing 6(1): 46-63.

Foa, Roberto Stefan, Andrew Klassen, Daniella Wenger, Alex Rand, and Michael Slad. 2020. Youth and Satisfaction with Democracy: Reversing the Democratic Disconnect?, vol. Cambridge. United Kingdom: Centre for the Future of Democracy.

Friedman, Rosa. 2017. What Next for the UN? World Economic Forum. https://www.weforum.org/agenda/2017/01/what-next-for-the-un.

Fullilove, Mindy Thompson. 2016 [205]. Root Shock: How Tearing up City Neighborhoods Hurts America, and What We Can Do About It, 2nd ed. New York: New Village Press. 
George, Susan. 2015. Shadow Sovereigns: How Global Corporations are Seizing Power. Malden, MA: Polity Press.

Jain, Ash, and Matthew Kroenig. 2019. Breathing new life into a rulesbased system - a global strategy. World Economic Forum Website. https://www.weforum.org/agenda/2019/11/breathing-new-lifeinto-a-rules-based-system-a-global-strategy/

Johnstone, Diana. 2020. The Great Pretext...for Dystopia--Review of COVID-19: The Great Reset. Consortium News. https://conso rtiumnews.com/2020/11/24/diana-johnstone-the-great-pretextfor-dystopia/. Accessed 21 Jan 2020.

Kaldor, Mary. 2003. Global Civil Society: An Answer to War. Cambridge: Polity.

Klein, Naomi. 2020. The Great Reset Conspiracy Smoothie. The Intercept. https://theintercept.com/2020/12/08/great-reset-conspiracy/.

Lissovolik, Yaroslav. 2019. Gaps In Global Governance are Holding Back the World's Economy. Here's How. World Economic Forum Website. https://www.weforum.org/agenda/2019/12/gapsin-global-governance-are-holding-back-the-world-s-economy/.

Markoff, John. 1999. Globalization and the Future of Democracy. Journal of World-Systems Research 5(2): 242-262. https://doi.org/10. 5195/jwsr.1999.135

Meyersfeld, Bonita. 2017. Committing the Crime of Poverty: The Next Phase of the Business and Human Rights Debate. In Business and Human Rights: Beyond the End of the Beginning, ed. C. Rodríguez-Garavito, 173-186. New York: Cambridge.

Munck, Ronaldo. 2002. Globalization and Democracy: A New, "Great Transformation"? The Annals of the American Academy of Political and Social Science: Globalization and Democracy 581: 10-21.

Norberg-Hodge, Helena. 2019. Local is our Future: Steps to and Economics of Happiness. East Hardwick, VT: Local Futures.

Oxfam International. 2020. Time to Care: Unpaid Care Work and the global inequality crisis. UK: Oxfam International.

Peet, Richard. 2003. Unholy Trinity: The IMF, World Bank and WTO. New York: Zed Books.

Robinson, William I. 2014. Global Capitalism and the Crisis of Humanity. New York: Cambridge University Press.

Robinson, William I. 2020. The Global Police State. New York: Pluto Press.

Santos de Sousa, Boaventura. 2006a. Globalizations. Theory, Culture \& Society 23: 393-400.

Santos de Sousa, Boaventura. 2006b. The Rise of The Global Left: the World Social Forums and Beyond. London: Zed.

Sassen, Saskia. 2014. Expelled: Humans in Capitalism's Deepening Crisis. Journal of World-Systems Research 19(2): 198-201. https://doi.org/10.5195/jwsr.2013.495.

Sen, Jai, and Peter Waterman, eds. 2007. Challenging Empires: the World Social Forum, 2nd ed. Montreal: Black Rose Books.

Sikkink, Kathryn. 2011. The Justice Cascade: How Human Rights Prosecutions Are Changing World Politics. New York: W.W. Norton \& Company.
Sikkink, Kathryn. 2017. Evidence for Hope: Making Human Rights Work in the 21st Century. New Jersey: Princeton University Press.

Sklair, Leslie. 2001. The Transnational Capitalist Class. Cambridge: Blackwell.

Sklair, Leslie. 2009. The Globalization of Human Rights. Journal of Global Ethics 5(2): 81-96. https://doi.org/10.1080/1744962090 3110235.

Smith, Jackie. 2008. Social Movements for Global Democracy. Baltimore, Md.: Johns Hopkins University Press.

Smith, Jackie. 2020. Making Other Worlds Possible: The Battle in Seattle in World-Historical Context. Socialism and Democracy. 34(1): 114-137. https://doi.org/10.1080/08854300.2019.1676030.

Smith, Jackie. 2021. Social Movements and Human Rights. In Human Rights: Politics and Practice, 3rd ed., ed. Michael E. Goodhart. New York: Oxford University Press.

Smith, Jackie, and Joshua Cooper. 2019. Bringing Human Rights Home: New Strategies for Local Organizing. Open Global Rights, https://www.openglobalrights.org/bringing-human-rights-homenew-strategies-for-local-organizing/

Smith, Jackie, and Dawn Wiest. 2012. Social Movements in the WorldSystem: The Politics of Crisis and Transformation. New York: Russell Sage Foundation.

Smith, Jackie, Scott Byrd, Ellen Reese, and Elizabeth Smythe, eds. 2011. Handbook of World Social Forum Activism. Boulder: Paradigm Publishers.

Smith, Jackie, Samantha Plummer, and Melanie M. Hughes. 2017. Transnational Social Movements and Changing Organizational Fields in the Late-20th and Early-21st Centuries. Global Networks 17(1): 3-22. https://doi.org/10.1111/glob.12152.

Standing, Guy. 2016. The Five Lies of Rentier Capitalism. Social Europe. http://eprints.soas.ac.uk/24833/1/five-lies-rentier-capit alism.

Steger, Manfred, James Goodman, and Erin K. Wilson. 2013. Justice Globalism: Ideology, Crises, Policy. Thousand Oaks, CA: Sage.

Tsutsui, Kiyoteru. 2018. Rights Make Might: Global Human Rights and Minority Social Movements in Japan. New York: Oxford University Press.

van den Berg, Esther, and Barbara Oomen. 2014. Towards a Decentralization of Human Rights: the Rise of Human Rights Cities. In Thijs van Lindert and Doutje Lettinga (eds.) The Future of Human Rights in an Urban World: Exploring Opportunities, Threats and Challenges. https://www.amnesty.nl/actueel/future-human-rightsurban-world: Amnesty International -Netherlands.

Publisher's Note Springer Nature remains neutral with regard to jurisdictional claims in published maps and institutional affiliations. 